\title{
Eared Grebe Colony in Regina, 1961
}

by Fred W. Lahrman, Saskatchewan Museum of Natural History

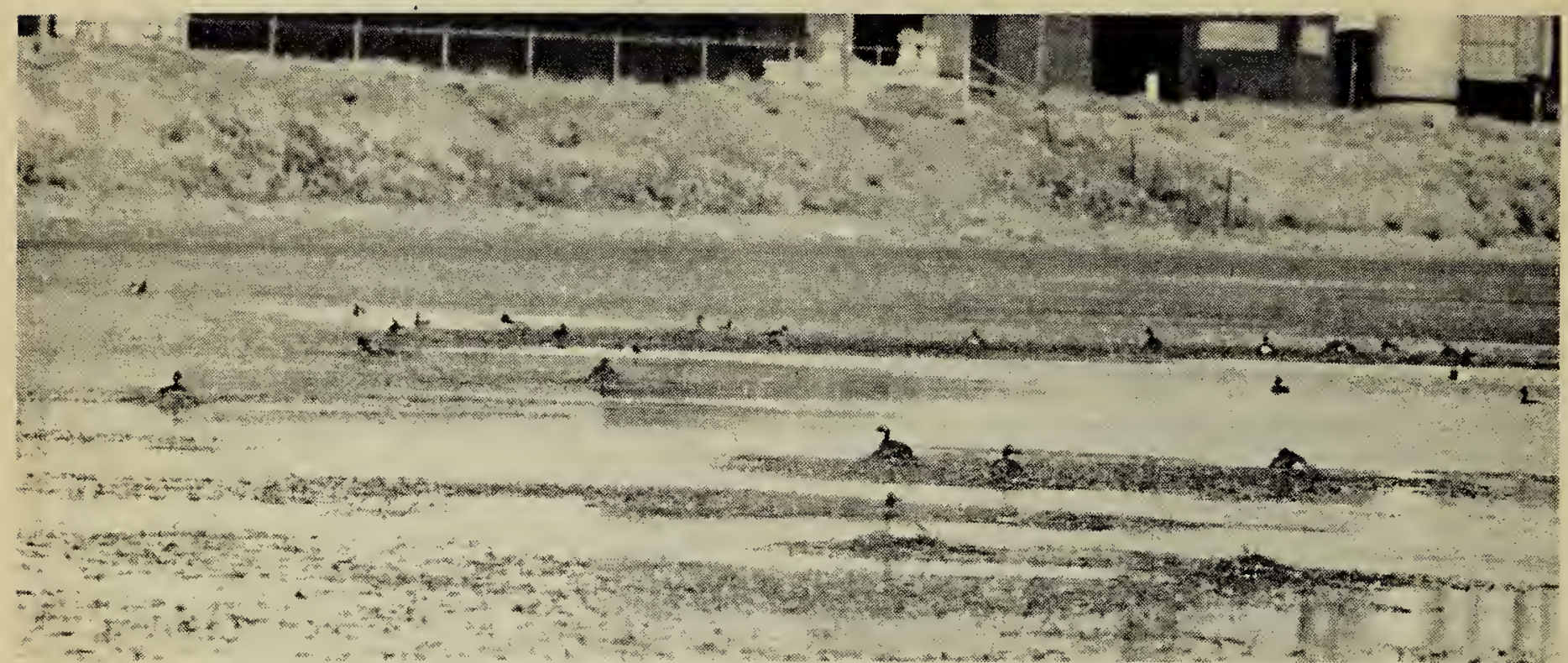

Fig. 1. Part of the main colony below the City Power House.

The series of photographs presented here shows the Eared Grebe colony which was under observation this summer (1961) at the Regina Waterfowl Park. The main colony, located below the City Power House (fig. 1) had 43 nests. In addition, five nests were built in another location in the Waterfowl Park near two Horned Grebe nests, the Eared Grebes apparently locating near the other nests because of their colonial nesting habit.

In figure 2 some of the nests in the main colony can be seen, built out in the water. Grebes of both sexes incubated the eggs, and in the photograph one grebe can be seen turning the eggs. The clutches of eggs varied in number from three to five.

The Eared Grebe is more common than the Horned Grebe on the Wascana. However, it is some years since a large colony has been located in the Wascana marshes. Eared Grebe colonies that we observed at the marsh during the 40's and early 50's, numbering up to 25-30 pairs, are reported by Margaret Belcher in the Birds of Regina (1961). A nesting colony of grebes such as we had the good fortune to observe and photograph this summer provides one of the interesting phenomena of the Regina Waterfowl Park where naturalists are striving to preserve a semi-natural marsh in the middle of the city.

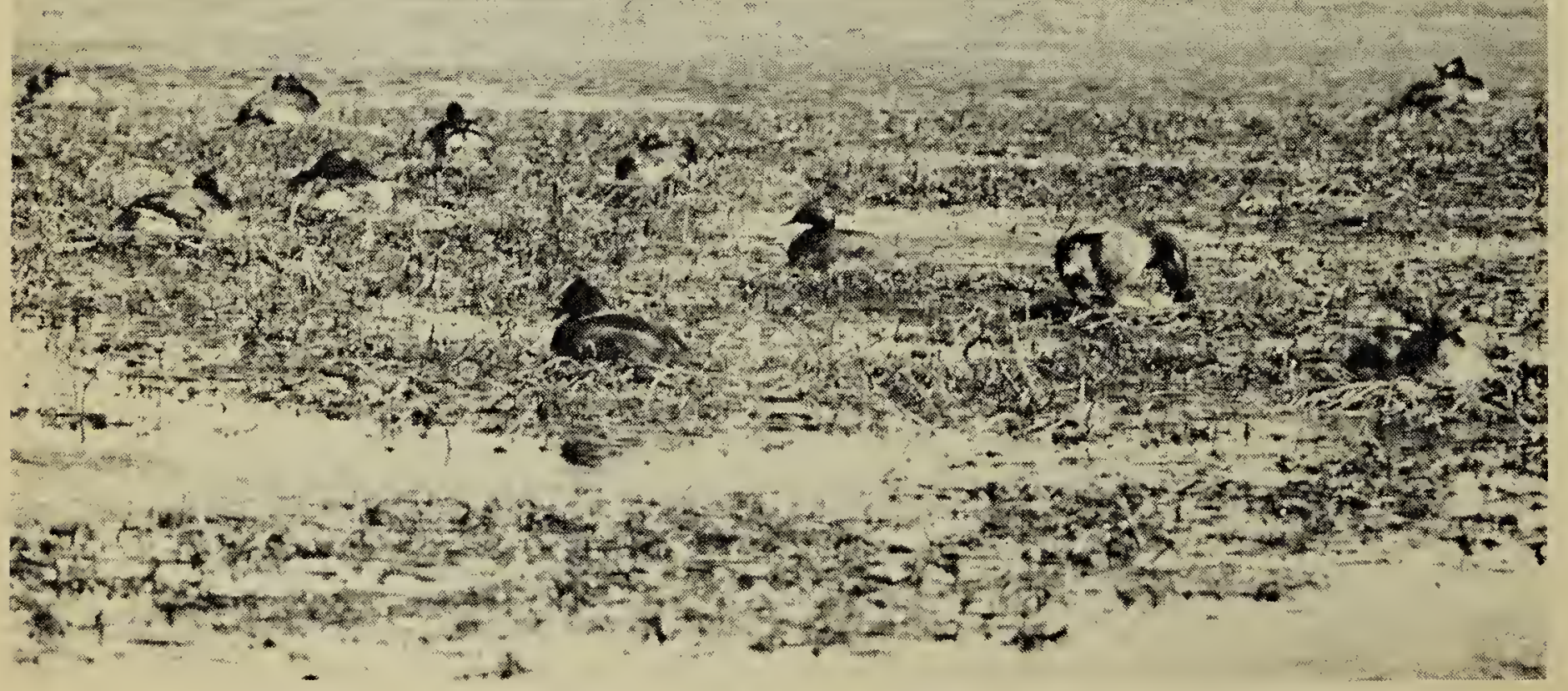

Fig. 2. Some of the nests in the grebe colony, Regina Waterfowl Park, 1961. 


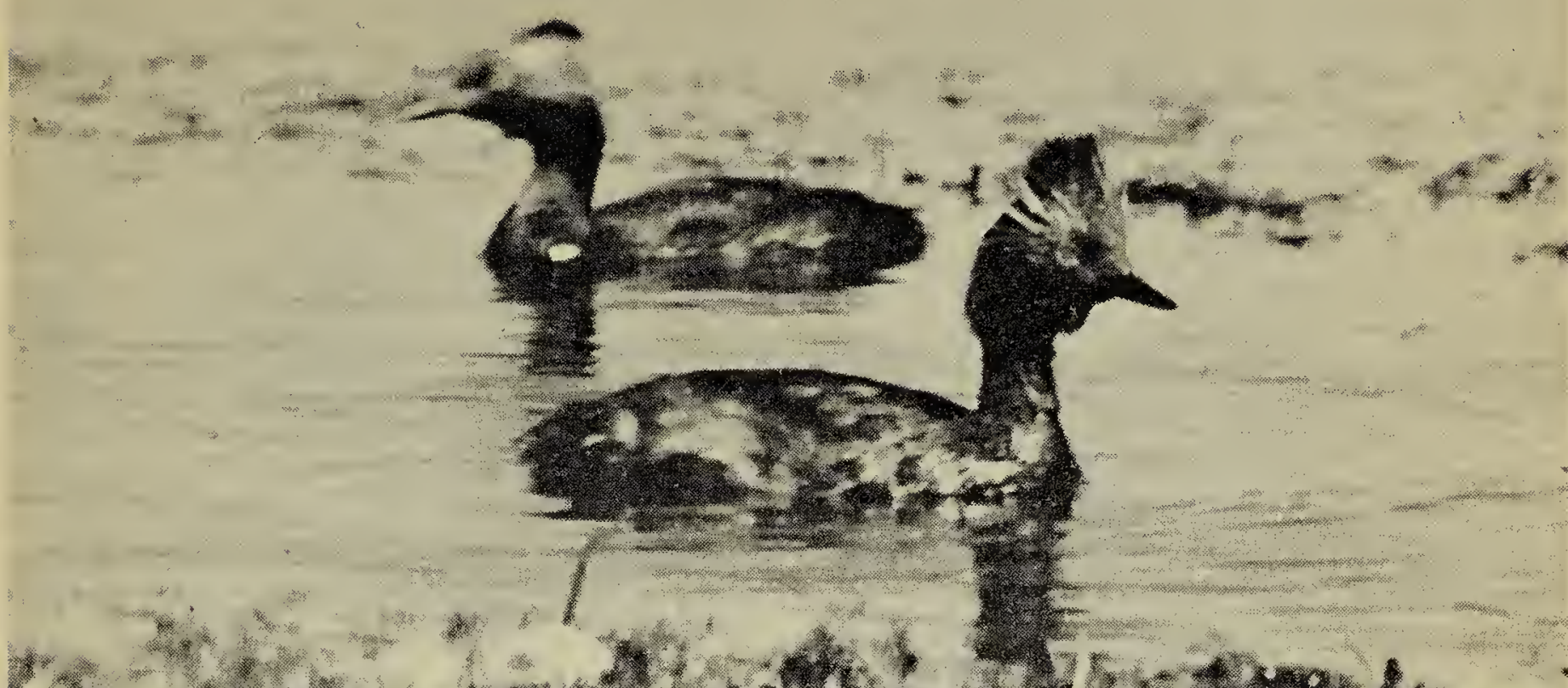

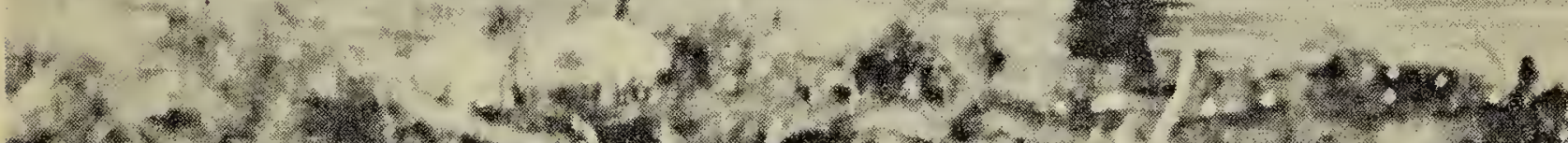

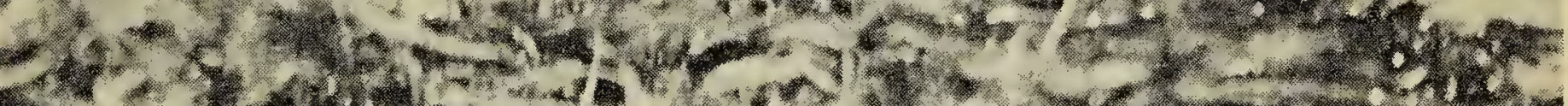

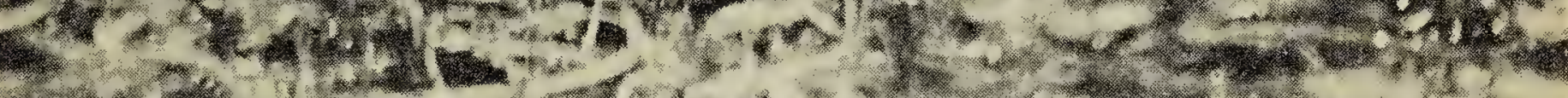

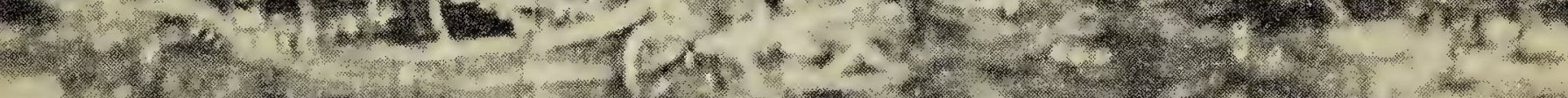

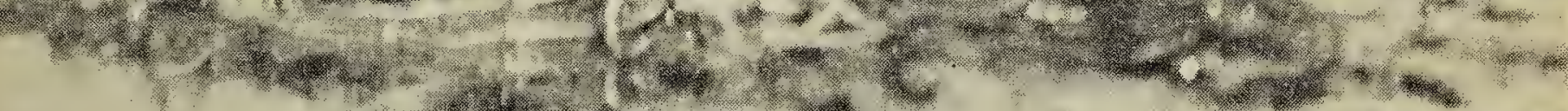

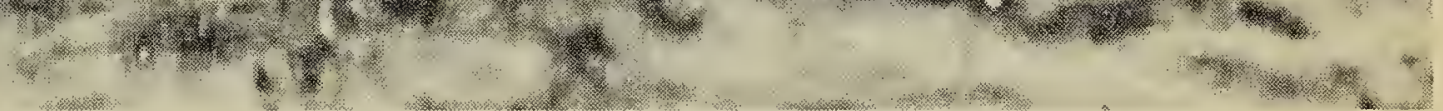

Fig. 3. Pair of grebes swimming near nest. Note characteristic profile of Eared Grebe.

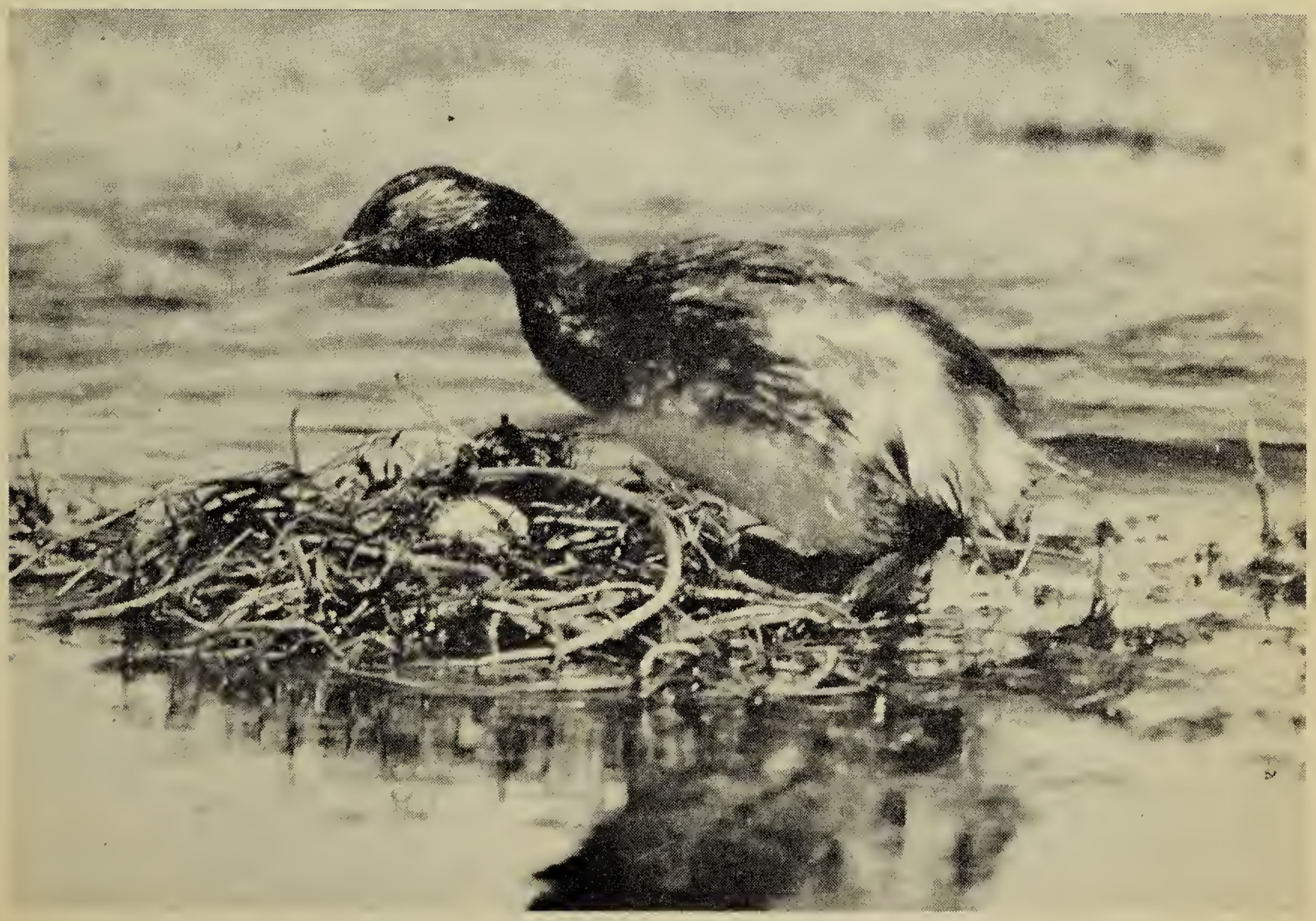

Fig. 4. Eared Grebe returning to its nest. 